\title{
Frontline reports
}

\section{'Rolling Thunder': Changing communication and the Pitjantjatjara Yankunytjatara public sphere}

DAVID I. TAFLER

Muhlenberg College, Allentown

7 OM O'REGAN and Philip Batty in Australian Television Culture, identify a problematic confrontation between westernised concepts of L 'publicness' and the notions of that 'publicness' found within Aboriginal cultural practices. O'Regan and Batty acknowledge the role that tradition plays in mediating the integration of indigenous communities within contemporary Australia. They suggest an array of issues that vary among communities. Some variables include proximity to European settlement, the traditional food sources, and the distance from the ocean.

Prior to the settler invasion, tradition played an important role providing the terms and forms under which this culture could be transformed. After the invasion the external input of settler claims introduced an important new transformative element alongside traditionally available means for managing social and cultural change. These external, principally European elements, modified, subverted or in extreme cases wiped out traditional forms of cultural management and transformation. Within this mix of tendencies there is no one pattern of Aboriginal life-ways or of symbolic ethnicity. (O’Regan, 1993, pp. 182-183)

In this context of dependency, governments intervene in order to encourage the development of Westernised forms of political discourse and practice that 
can mediate between the larger white mainstream and the deep particularity of Aboriginal culture. That intervention seems to evoke the possibility of a re-colonisation of an already fragmented and economically oppressed culture. The concept of a Public Sphere as found in the West and emblematised in the work of Habermas, with its overtones of rational debate and democratic forms of discourse and interaction, sits uneasily with Aboriginal practices and community protocols.

As the axis of state intervention shifts from the top-down policies, associated with colonialism, to a post-colonial situation, where bottom-up strategies emerge, the formation of an Aboriginal public sphere becomes an historical possibility. Unfortunately, problems arise. As Regan and Batty observe, the formation of an Aboriginal public sphere gets caught up in hegemonic struggle over which values will have priority, all the while riven from within by tribal factionalism and economic dependence on Government funding as a welfare provision rather than as compensation for the loss of lands and resources (Perkins 1990, p 11). As the concept of hegemony suggests - of cultural and political struggle to reconcile a subordinate value system with a ruling framework of values - this process of incorporation does provide some positive aspects and opportunities for an Aboriginal empowerment and cultural revival.

Such bottom-up policy developments erupt from difficult conditions and complex politics on the respective self-rule territories. On the Pitjantjatjara Lands today (five hundred kilometres south of Alice Springs in central Australia along the border of the Northern Territory and South Australia), three thousand people live scattered in approximately a dozen communities and in another dozen satellite homelands. A challenging physical climate, limited resources, relative isolation, and the small population have made the transition to a productive, self-sustaining European or Western model society difficult if not impossible. The enterprises that do exist, such as tourism and art and craft production, offer a small and insufficient remedy. The same applies to ranching. The only "real" option, mining, threatens the integrity of the land and the social order. In short, the people remain dependent on government support and face a host of problems-medical challenges, the loss of a self-sustaining way of life, boredom, substance abuse, crime and despair.

As O'Regan and Batty argue, despite these real difficulties the indigenous culture can adapt and survive, as it has done for thousands of years: 
Aboriginal culture, like all other cultures is emergent, not static. It is the product of contestations, divisions and the mobilisation of resources by particular agents within the terms provided by cultural and social systems. To fail to accord it that much is to fail to recognise a culture's transformative capacity and therefore to regard any indication of cultural transformation on the part of Aboriginal communities as becoming less Aboriginal, more modernised, westernised. The contours of contemporary Aboriginal culture are also necessarily defined by what Aboriginal tradition and the set of practices associated with it permit to be transformed, what the settler culture permits Aborigines to do within it and to appropriate as their own of the settler culture. (O'Regan, 1993, pp. 180-181)

This article provides an eyewitness account tracing the struggles around the formation of an Aboriginal public sphere, a sphere that speaks to different values and lives under permanent pressure to adapt to the mainstream norms of White Australia.

\section{The realm of the Pitjantjatjara}

The everyday evolution of the Anangu (the name for the 'people' of the Pitjantjatjara, Yankunytjatjara and Ngaantjatjara tribes) public sphere revolves around traditional patterns of knowledge ownership, protection, retention, and transmission. Old patterns of information exchange, however, still privilege particular groups in different ways at different times, in particular those organised around family. Strict rules dictate a hierarchy of relationships whereby particular individuals have greater authority, determined by gender, age, spiritual responsibility and property. Traditional law guides the genesis of this social arrangement. Initiation rites mark the entrance into this knowledge order and earmark responsibility for the initiate. Anangu face the difficulties of accommodating those traditions in light of their ongoing and relentless integration with an outside and very different world. Recent declining levels of government support have exacerbated efforts to balance internally the respective interests.

With the money flow determined by outside agencies, the governing Anangu Pitjantjatjara Council plays a more difficult middle management role in the everyday decision making process. When funding diminishes, the everyday living situation grows dire and tensions increase. Decisions have 
broad ranging economic and social consequences. The drive toward consensus does not necessarily accelerate with the need for action. Corruption grows. Family members prioritise their family needs. Family leverage determines representation. In this circumstance, the council's intention to sustain a more democratic and representative governing system are increasingly stymied inviting outside intervention.

Some of the crucial issues currently generating widespread public discussion on the lands include the question of mining: the granting of permits, consideration of the environment, the effect of outsiders, the problem with grog, education and youth, the allocation of diminishing financial resources, the challenge of supporting a global infrastructure, and all of the above while sustaining traditional ways of life. Other issues address housing, employment, substance abuse, health and nutrition, access to money reserves, supporting infrastructure - water, sewerage, electricity and roads.

Complicating matters, a number of tragic events have drawn the attention of the state media and government. Those outsiders have threatened to revisit the legislation establishing the governing councils, not to mention revisiting the law ensuring the freehold status of the people on their lands. Such actions would mitigate the regional autonomy and the ability of the local indigenous population to direct their own affairs. Corporate mining interests might have much to gain. Local families supporting state government initiatives would similarly have certain advantages.

The Minister for Indigenous Affairs, a part of the state bureaucracy in Adelaide some 1200 kilometers to the south, remains relatively insulated, depending on reports from the north to gauge conditions on the Lands. When the Minister does visit, he flies up to the Lands for a couple of hours, has discussions, tours communities, forms impressions, and returns to his more comfortable sleeping quarters in Adelaide with only a superficial understanding of the people or the culture. Meanwhile, Anangu leaders have to devote that much more energy to assuring and reassuring those government figures committed to improving life on the lands. Patronage and power inform the interaction here as elsewhere.

Family privilege on the Lands does not necessarily depart from practices that privileged ownership by groups on the outside play in the control of corporations and institutions, in particular the control of media. On the surface, it appears that the privileged family structure on the lands does allow 
certain groups or individuals the opportunity to exercise the same control over media as other families do over health care, land management, property allocation, community operations, not to mention traditional responsibilities. On the lands, however, control and ownership remain far more integrated into a shared social order. One group cannot monopolise information any more than they can monopolise any other operation despite claims to that effect.

\section{Enter the media}

Control of the media becomes a new battleground. That control challenges traditional boundaries. The proliferation of new media on the lands accelerates accommodation to outside values, political practices, and economic determinants. Under the new media umbrella, the family distribution of power and responsibility no longer limits access to and participation in the prevailing debate. Through the new media, other family groups now have equal access and can lobby for greater control.

Further north, Eric Michaels, an American visual anthropologist, worked with the Warlpiri people to establish their media organisation in the 1980s. When writing about Warlpiri culture, Michaels pointed out the complexity of dissecting the culture and assessing the value and meaning of any one single component or representation alone. For example, Michaels argued that an examination of notation in painting or video necessitates deciphering its operation with the broader systems of kinship and world outlook. Those systems go back thousands of years.

The creation and recreation of the world is an established eternal process; the stories, songs, dances, and designs that contain and explain these truths are likewise unchanging. What one paints or sings or dances is what your fathers and mothers and their fathers and mothers painted, danced, and sang before you (although one may acquire additional information about these truths through revelation or exchange). Your rights to do the same are determined by your position in an elaborately structured system of kin, itself handed down along with these expressive arts from the ancestors themselves. (Michaels, 1984, p. 86)

When new technologies emerge, they apply pressure to all parts of a system that established rules and hierarchies for the transmission of information across 
many generations in an almost timeless manner. To harness the new forms of communication, proponents must often assume a more pro-active role generating a tangled crossover effect across traditional boundaries.

By 2002, the 'organs of information and public debate' on the Lands consisted of (1) word-of-mouth, public meetings -usually aired outdoors in the centre of a community, and (2) the Radio 5NPY FM network narrowcast in all of the communities and available by satellite dish transponder in remote homelands. Harnessing these platforms to a much greater degree than in the past, through a campaign labelled Rolling Thunder ('first comes the lightning, then comes the thunder'), the local governing council tried to build the essential consensus that would resolve important disputes and lead to particular governance directives. The Rolling Thunder campaign aspired to go beyond simple reactive measures. Recent administrative divides and struggles on the Lands have threatened the viability of this dependent state 'democracy'.

The notion of 'democracy' begs the question. Traditional indigenous society bears a strict authority hierarchy based on laws formed over thousands of years. The laws ensure justice, fairness, and a widely distributed social well-being. Decision making rests with the elders, educated and experienced leaders in the community. Introducing a 'Western' or European style voting process violates the traditional ways of building consensus, which require time and patience.

A more intimate public sphere has the capability of not only surviving but thriving in a small community, which has few of the economic burdens of a time-managed economy. That small community has, however, become a smaller part of a much larger 'community' and, therefore, must adopt its governing traditions to the demands and constraints of the outside.

In the past, discussion time had fewer imperatives. Now, in a larger world, that has changed. Outside funding dictates decision making in a timely manner. New communication tools provide the arena for accelerating the debate, for bringing people together, for enabling them to make those decisions in the timely manner dictated by outside forces.

New media campaigns help to transform this older public sphere by building new highways for opinion and consensus formation. ${ }^{1}$ Because of the small population, media can allow for unhampered communication with each individual afforded the opportunity to speak and bear witness. The activities of the organisations themselves can come under much greater scrutiny. Prob- 
THE INDIGENOUS PUBLIC SPHERE

lems arise, however, when it comes to institutionalising the use of this 'new' media. Old forces engage the newer efforts. Those old forces adhering to the traditions threaten to slow the momentum toward a change in the construction and engineering of the public sphere.

\section{The Rolling Thunder campaign}

In 2002, the governing AP Council on the Anangu Pitjantjatjara Lands decided to take some initiative and respond to the external pressures from the state to resolve the ambiguous governing relationship between the council and the people, between its own council and the predecessor council, the Pitjantjatjara Council based in Alice Springs. Each council had its history. Each represented the interests of particular groups within the larger society.

Much criticism centered on local governance. Frequent changes in administrative support led to a lack of outside state confidence and to a confirming low level of operations (the lack of minutes at meanings, the nonrecording of resolutions). The AP Council also set a bad political standard. Insufficient communication across the lands (no newspapers, little radio coverage) favoured those chosen representatives who might claim to represent their constituencies, but privileged their own family interests.

As a spearhead to community reform, the leadership of the AP Council organised a travelling campaign, a campaign eventually labelled 'Rolling Thunder', to bring the self-governance debate to the communities and to allow the people to consider openly the development of a governing constitution.

The organs of information and 'public debate' on the lands consisted of word-of-mouth, public meetings - usually aired outdoors in the centre of a community - and the Radio 5NPY FM network narrowcast in all of the communities and available by satellite dish transponder in remote homelands. Using these platforms, individuals tried to build the essential consensus that would resolve important disputes and lead to particular governance directives. Going beyond simple reactive measures, recent administrative divides and struggles on the lands have placed pressures on this dependent state 'democracy'. In response to these pressures, the Rolling Thunder campaign evolved from a commitment to preserving the structured system of discourse while allowing it to evolve within the emerging telecommunication environment. 
Rolling Thunder revolutionised the public sphere on the Pitjantjatjara Lands. The campaign cut through the arbitrary geographic and political boundaries of the communities. ${ }^{2}$ The campaign reached every community on a set schedule, stretching out the political and social discussion over several weeks in order to include all interested participants regardless of their location.

Lee Brady, from Nyapari, summarised the issues germane to the Rolling Thunder campaign:

- The Executives [the members of the Council] should be strong leaders, good spokespeople, with a command of the issues. Each community should have a representative.

- The Executives should be elected to three year terms, with an annual review.

- The Chair should be an annual appointment. If the Chair is not reelected, he should be prevented from running again for three years.

- The Executives should be financially supported by the Communities.

- The Executives should be professionally trained.

- The Executives should be working to keep money on the Lands: taking over franchised business concessions like the sports carnival stands; operating a bank.

- The Executives should oversee banking and tourism.

- Spiritual and Cultural criteria should not be used as criteria for choosing Executives. ${ }^{3}$

Rolling Thunder's evolving slogan 'first comes the lightning, then the thunder', articulated the campaign's eventual goal of reinvigorating community political participation.

The prospects for developing a culturally sensitive and efficacious form of 'public' sphere still officially revolve around the local governing council. Over the last two years, the governing council of the Anangu Pitjantjatjara Yankunytjatjara Lands has undergone a series of shifts. The respective candidates have campaigned using both the new technologies (radio and fax) and the old (word of mouth and family ties). Administrative changes represent the give and take of different family and tribal forces oscillating between existing power structures - long-term internecine feuds mixing with an emerging generation of leaders. Each group negotiates a different relationship with the media depending on its vested interest in either sustaining current levels 
of political activity or increasing the input of more marginal or remote constituent communities.

Viewed positively, the new media systems harbour the capability of moving information more effectively horizontally rather than having its dissemination dependent on the more rigid vertical flow down from the more privileged groups and families. ${ }^{4}$

Much of the Warlpiri 'Aboriginal invention of television' in Central Australia as Eric Michaels [1986b] described it is concerned with finding ways of incorporating settler Australian media and technology into the traditional Warlpiri mechanisms for constituting social and cultural reproduction. Television and telecommunication systems are being used to reaffirm Aboriginal cultural identity and life-ways. Michaels [1985, pp. 505-10] argues that as traditional Aboriginal society is an information based society, television represents important means, in Francis Jupurrurla's words, to fight 'fire with fire' by reconstituting Aboriginal communication networks and promoting an expansionist Aboriginal program reclaiming land, information and dreamings [Michaels 1987b, p 74]. Television becomes opportunity, not threat. (O’Regan, 1993, p. 183)

In fact, 'fighting fire with fire' did not work. Outside television proved far more seductive than the local low production efforts. Indigenous people harbor the same fascination and media obsession as do people in other parts of the country and world. So whereas indigenous television struggles to compete against the seductive programming of outside media, in particular sports, radio offers an alternative and less problematic sphere. Radio offers the extension of the conversation around the fire, of the community meeting space. Here, the talk radio models prevalent outside the indigenous communities simply reinforce that mode of use on the lands.

In this aspect, Rolling Thunder reinvigorates a tradition that began with the introduction of HF wireless transmitters among the various cattle stations on the land. HF 'radio' became a central square on the air where anybody could listen to anybody's conversation. At regular intervals usually in the early morning, Yami Lester and other elders would reserve the airwaves for news and information of general interest. This system withered with the arrival of telephones, devices that privatised information. Meanwhile, tel- 
ephones failed to serve the people because of the impossible economics of building and sustaining a remote network.

Radio came to the Pitjantjatjara Lands in 1997 with the establishment of the Radio 5NPY network. Radio represents the cornerstone, but only the beginning of the telecommunication changes underway. The more recent revival of a new and now affordable wireless UHF/CB highly interactive communication network that allows any individual to transmit at any time from almost anyplace on the lands, augments that radio network and perhaps even supplants it as a forum for political debate. Now, everyone can participate in an open discussion of the major issues of public concern at any time, not to mention sharing corollary information among many individuals. This goes a long way toward reunifying the people. It permits all individuals to participate at all times from their respective location across the lands. Space (location) becomes immaterial. Nobody has to organise the forum and everybody can have the capacity to stay informed. Information passes across the lands in horizontal waves in defiance of the traditional vertical order. In a community-based system where nearly everybody knows everybody else, every voice has an audience. Those voices that vacillate reveal themselves. Every message becomes accountable in ways impossible to conceive on the outside. This departs quite dramatically from the larger society with more specialised media where assigned spokespeople have the responsibility for targeting and representing groups of people.

The Rolling Thunder campaign on the Pitjantjatjara Lands pre-dated the emergence of the now revived one-to-one-to-many wireless UHF/CB communication network. It did help set the stage. The campaign marked the web of relations unfolding across the now-public broadcast sphere. It marked the last stage of the evolution of a public network radio service. In particular, it marked the maturation of radio as a system for establishing a new public sphere on the Pitjantjatjara Lands. That use of radio departs dramatically from that on the outside. Here, radio's forum still adheres to historical, family traditions. Radio models itself on the Anangu traditional discussion space, the public debate around the fire, in the sand, stretching over time.

Environment, always a major player in shaping the public sphere on the Lands, now plays a diminished role in shaping communication. Wireless means of communication unite a widespread sparsely populated region. Time, traditionally tied to the physical cycling of the days, the moon, and the seasons - phenomena bound by the Anangu relationship to daytime and nighttime 
light, to the wind, to the intermittent rain, and to the seasonal temperature becomes an imperative dictated by funding cycles, obligatory election campaigns, work and commerce.

In the same way that new wireless communication conduits alter the traditional relationship to time and space, access to information, how and to what extent each voice gets heard, changes the old family structures. Anangu leadership revolved around family interests. Different families moved into different positions of responsibility and power. As time evolved, a carefully negotiated balancing act transpired over hours of discussion, a history of appropriation. The families divided power and influence within the different communities, and across the lands through the respective oversight agencies - media, land management, basic services, health, and overall administration.

\section{Renegotiating leadership}

Ironically, during the first flush of self-management in the 1970s, better communication and support helped establish a generation of leaders. Now, that generation looks for younger leadership. Time to recruit the younger fellas, who studied in Adelaide and returned to the lands with nothing to do. The role played by those younger leaders has become more critical. As the media environment in Australia and around the world stretches and expands, remote areas become less and less remote. The now-inescapable presence of the 'outside' forces the negotiation between the old ways and the new. Each new invention increases the number of points of contact. The use of a portable radio transmission feed to bring a traditional 'town meeting' to a widely dispersed audience may seem insignificant in the early 21 st century. On the contrary, it revolutionises a society whose system of discourse - sitting down in the sand - has evolved from 50,000 years of law and tradition.

At the time of the Rolling Thunder campaign in 2002, the Pitjantjatjara Yankunytjatjara Media (PY Media) director, Donald Fraser, told his Anangu staff 'that during the day Anangu workers must operate like white fellas' ${ }^{6}$ 'Radio and video works in a white fella system'. To dramatise his point, Fraser took off his glasses, pointed to them, and suggested that 'the glasses represent white fella way'. By contrast, he explained 'that black fella way would limit me to sitting under a tree, blind and useless. The glasses help me to see well. After work, Anangu can go back to black fella way'. Fraser spoke 
of his pride for the Anangu workers. He encouraged them to learn for someday, they would take over the white fellas' jobs.

Despite Fraser's logic, Rolling Thunder had a mixed reception. The public sphere still had to adhere to black fella tradition. Some speakers, such as Lee Brady of Nyapari, met the Campaign in Amata, but waited for the Campaign to come to his land, Nyapari, before speaking publicly ${ }^{7}$ Some Tjilpis (elders) voiced their concerns. They asserted their preference for the traditional 'vertical' verses the now 'horizontal' distribution of information. They wanted Rolling Thunder to talk first to Tjilpis, educate them so that they understand the issues. The Tjilpis would arrive at a consensus. Afterwards, the Tjipis would call the meeting of the people. 'Young people leave Tjilpi and go wrong way - drinking, smoking, putting needle, stomach. They have accidents and they often die. Too late for the straight road.'

The Tjilpis resented broadening the public sphere to bypass the representative experience, where individuals and groups had to channel their sentiments through spokespeople (chosen in traditional ways, of course) who then operated in a closed forum. Now, everybody had a voice in a public forum that stretched across the lands. This redistribution of power threatened traditional hierarchies predicated on experience and knowledge, and often family.

When the campaign began rolling across the lands, the public forum endured as a daily serial event. With the loss of parliamentary safeguards, the tyranny of public opinion shaped the public debate. As Rolling Thunder moved from community to community, the people, prepped by the previous days' radio broadcasts, added to the intensity of the experience. The evolution of the conversation through this sequence of public forums built over time. Each individual within each community could approach the microphone as many times as he or she desired. Each community awaited its opportunity to contribute to the public debate. With that intermittent timetable, the interjected revelations and the surrounding political intrigue, tensions built and tempers flared.

\section{On the road}

Normally, the everyday routine of community life harbors little excitement. By comparison, the Rolling Thunder constituted a real presence, a significant event. In each community, the Rolling Thunder campaigners arrived, con- 
ferred with local leaders, set up the equipment, made the radio linkage, and began the meeting. People gathered, dogs fought, Peter Nyanangu sang a small celebratory song as part of his welcoming, the rhetoric intensified, the campaigners posed the fundamental questions of political reorganisation. After everybody had their say, the discussions ended with the reading of the articles for constitution. People yelled out their endorsement of each position. Donald Fraser picked up a handful of dirt in one community to dramatise that the land belonged to the people. Fraser declared 'the people have made the law that will speak for their community'.

In the wake of the meeting, the organisers conferred again, packed up the equipment, reviewed strategy, made adjustments to the schedule, climbed aboard their vehicles and continued down the track. Pulling off at some mulga patch or clearing, they stopped, set up camp, built a fire, rolled out the swags, cooked dinner, and continued revisiting the day's events.

On Tuesday, 13 August 2002, the Rolling Thunder group arrived in the Amata Community, 110 kilometres west of the administrative centre Umuwa. ${ }^{8}$ This typical quiet morning in Amata, typified the type of experience the campaign evoked. Bill Davies and his son Rory arrive first and begin to set up loudspeakers to draw people to the centre of the community and to make the discussion accessible for the surrounding residents. A short while later, Will Rogers, general manager of PY Media arrives, and sets up a radio transmission link that connects the microphone on the loudspeaker system, via phone lines, to the Umuwa hub of the Radio 5NPY network. By this stage, Leonard Burton, community leader, has already begun to address the community over the loudspeaker system in anticipation of a growing audience. Initially, Leonard's impassioned rhetoric seems to serenade the sand. Gradually people in the community congregate around the open space. Rogers confirms radio linkage, A stream of monologues from a broad number of people, men and women, goes out over the Radio 5NPY network across the Pitjantjatjara Lands.

An hour or so into the session, 20 people and ten dogs sit about the open space. By late in the two-and-a-half hour meeting approximately 30 people and ten dogs sit and mill about the central 'square'. A group of children play ball. The public space spreads beyond the line of sight. The loudspeakers spread the discussion to a larger audience of people congregating in front of their homes. The Radio 5NPY network broadcasts the meeting to an even 
larger audience of perhaps a thousand people, a third of the population across the lands.

Throughout the Rolling Thunder campaign anywhere between 25 and 50 people usually congregated in and around the community center. Sometimes an awkward set-up evolved in the open space. A group of women might gather behind the speakers and a group of Tjilpis on the far side. Some pockets of people spread about the community, with a few camped in their cars. The speakers seemed to project their message beyond any particular group gathered in the proximate area.

The real negotiation transpired not in the foreground of the community meeting, where the speakers gathered at the microphone, but in the background among the small clusters of individuals seated around the community. In those smaller groups, people listened to the speakers, conversed, and either reached consensus or, at the very least, defined the issues. All of the myriad components of the environment - the freely roaming children, the freely roaming dogs, the passing vehicles, the drinks and cigarettes, helped mediate the conversation. Toward the end of the gathering, the petrol sniffers arrived. ${ }^{9}$ Despite all the talk, the petrol sniffers wandered about unperturbed, as one speaker stated 'lots of words, no action'. ${ }^{10}$

Rolling Thunder's tangible presence within the community supported the construction of its new virtual arena for the existing public sphere. The electronic portal depended on its material platform. In other words, a material setting in the community set the stage for the electronic platform that reached across the lands. The electronic platform reaffirmed the legitimacy of this public space. It commanded the attention of the networked audience.

The extended (spatial and temporal) public dialogue reins in everybody's responsibility to not only participate but to abide by a larger consensus. On the other hand, a larger group creates a more difficult path toward consensus.

Such political tensions are taking place in the context of a more organised Aboriginal public sphere than in the immediate past. ATSIC's representative structures, the formation of a self-proclaimed This includes an emerging politics of representative governance by Aborigines themselves as the instruments of Aboriginal-state involvement shift from a relatively non-transparent welfare-based management of a subaltern and supposedly recalcitrant group in need of modernisation, towards selfmanagement and representative governance. (O’Regan, 1993, p. 186) 
Communication, meanwhile, accelerates the speed of discussion, which, in turn, crystallises the issues. The leadership sponsoring the campaign no doubt hoped that the speed and facility might impact on outcomes.

No criticism of the process mediated the discussion. Many different people spoke. Anybody and everybody had an opportunity. The old fellas, extraordinary orators, stood and spoke their minds with the fluidity of seasoned politicians. These speakers had already earned their legitimacy based on the codes and standards of their social status. Their rhetoric reconfirmed that status. Anybody, however, could respond and everybody could listen regardless of taboos.

Over the course of the discussion, the content ranged across a spectrum of issues directly and indirectly bound to governance. Some people expressed their dismay over conditions on the Lands. One woman said that after Anangu recovered their land 20 years ago, things had got progressively worse. ${ }^{11}$ She claimed that communication had broken down. Several people accused 'Umuwa' (the administrative centre, a de facto capital of the Pitjantjatjara Lands) of being 'clogged up'. ${ }^{12}$ The people, however, acknowledged not knowing much about the activity transpiring in the administrative offices both in Umuwa and in the communities, places where people made everyday decisions about money, resources, and the various projects that affected them directly. When the meeting concluded, the nearby community 'store' reopened. People grabbed some lunch and continued their conversation.

Though the organisers meant the rhetoric to address the formulation of a constitution, much of the talk sounded like a lament. A couple of the women and a couple of Tjilpis talked about the overall decline in the quality of life in their community over the past number of years. They lamented how they had won back their land but lost control of their destiny.

A vast land unified by a common interest posed big problems. Old forms of communication broke down. People lost control.

The Anangu Pitjantjatjara governing council started off as a small dot. It kept growing until the many layers became non-navigable by the average Anangu. Umuwa, the administrative centre, got bottled up. Now, no one knows what the council does with the money.

The people talked about the three scourges brought by the white fellas: alcohol, petrol, drugs. One woman talked about how weak everyone had become. 'The government gives money for all sorts of things, and the people 
become weak'. She continued. Adults allow children to run around without any responsibility. By the time they reach adulthood, the young people have become weak and cannot assume the responsibilities of an Anangu adult.

Bill Davies, one of the Rolling Thunder organisers, recounted a story from the community of Pipalyatjara. Years ago, when rampant petrol sniffing afflicted the community, one family remained unaffected. One day a 12year-old in that family tried petrol. The family came down on him in force. Stripped of his clothing, the boy had to walk around naked for three days. Consequently, his petrol sniffing ended as quickly as it had begun.

In many communities, a pro-active family approach happens rarely. Moreover, within the Anangu public sphere, Anangu will not reprimand another family's petrol sniffing children for fear of reawakening inter-family disputes that have been festering for more than 40 years. Bill Davies explains: Anangu operate within an entirely different public sphere, a mindset difficult for white fellas to understand. Anangu move forward into the future by looking backwards at their past. Anangu cannot move ahead without looking behind them, at the law, the way the ancestors did things for generations and generations. Over the duration of that fifty thousand year old history, however, no precedent exists for today's petrol sniffing or other problems. Therefore, Anangu lack the cultural equipment for dealing with contemporary problems, a conundrum. Eventually, according to Davies, they will work it out and move collectively. That movement will mandate a reconfiguration of the public sphere, away from the traditional family power base to a more community based system of authority. Toward making that transition, talking builds a vision that can guide the community to act collectively. Anangu will rise up together to address their problems or they will fail.

Many ironies inform the conversation. Peter Nyanangu mentioned the irony of hearing another Tjilpi, Kinyin, speak for the strengthening of the AP Council. Kinyin, a member of the Pitjantjatjara Council Executive, plays dual roles. The AP Executive can decide one thing on one day. A few days later in a very different context, the same members can join a Pitjantjatjara Council Executive decision that goes in the exact opposite direction. This 'kati kati' may seem like a contradiction in outside terms but it represents one of the long-term negotiation ambivalences that help to forge consensus. Needless to say, resolution takes a very long time. These shifts and adjustments will test the patience and heighten the frustration of outside observers, par- 
ticularly those from governments responsible for funding and overseeing life on the Lands.

Bill Davies told an anecdote that illustrates cultural paradox. During a CAFL (Central Australian Football League) game, a player allowed his opponent to make a mark. He made no effort to block the catch. He would not interfere. Apparently, family restrictions inhibited his looking at the opponent or interfering with his action. The opposing players had to adjust their play to conform to traditional law.

\section{Conclusion}

For all its limitations, the Rolling Thunder campaign marked the restoration of communication. As Eric Michaels suggested in his writing, the conditions of transmission helped shape the discourse, the text. Each individual who has a voice on the air becomes a media practitioner. According to Michaels, the messages

may or may not be easily identifiable in that text itself, especially if we are not trained to look for them. This requires that we expand the critical analysis to consider evidence of the conditions of making, transmitting, and viewing, and to acknowledge that texts come into existence, and must be described, in terms of social relations between institutionally situated audiences and producers, and that meanings arise in these relationships between text and context in ways that require a precise description in each case. (Michaels, 1994, p. 21-22)

Understanding the emergence of the 'new' public sphere on the lands means examining the subset of relations governing discourse between family members and among families. Each statement operates within a frame formed by thousands of years of tradition. An understanding of the metamorphosis of that tradition when warped by the public airwaves, not to mention other forms of media such as television and the internet, requires decades of observation.

Mitigating an argument for total outside government intervention, Anangu culture and traditions offer important insights. The traditional relationship with flora and fauna contribute to the body of scientific knowledge. The social order models alternative ways of negotiating property and privilege that may become increasingly important to future society. At the very least, this family centered, even feudal society offers an important laboratory for 
testing the impact of alternative community models on a public sphere increasingly mediated by advanced communication technology.

\section{Notes}

${ }^{1}$ This article tries to avoid deliberating between the respective parties and the relative merits of their political platforms. It also acknowledges that an outsider provides the overview. That might limit the subtle understanding of the described situation but balance that with an enhanced sense of perspective. A different public sphere operates in the central desert indigenous tribes of Australia. The writer who operates outside that (family) sphere writes with fewer political boundaries.

${ }^{2}$ First, the missionaries constructed those communities and later the government sustained those communities as part of an effort to administer more efficiently the 'civilization' of the people and the support bureaucracy on the 'lands'.

${ }^{3}$ The Tuesday, 27 August 2002, second Rolling Thunder meeting in Amata began around $11.45 \mathrm{am}$ and ended around $2.30 \mathrm{pm}$. During a considerable portion of the meeting, Lee Brady prepared his thoughts but decided to wait for the Rolling Thunder Campaign to arrive in his community where he felt empowered to speak.

${ }^{4}$ Jurgen Habermas, trans. by Thomas Berger (1989) The structural transformation of the public sphere: An inquiry into a category of bourgeois society (Cambridge, MA: The MIT Press), p. 213.

${ }^{5}$ PY Media project has placed CB radio towers across the lands. This allows anyone from one end of the Pitjantjatjara Lands to the other to remain in wireless contact while on the major tracks and inside most of the communities and homelands.

${ }^{6}$ Umuwa, 21 August 2002.

${ }^{7}$ The Wednesday, 28 August 2002, meeting in Nyapari began at 11.30am. Keith Stevens, who had telephoned during the Fregon meeting a week earlier but hung up uncertain about his presence on the air, spoke strong words. Lee Brady spoke his points. He mentioned a road near his home called 'YAPA'. He used YAPA, which means Yankunytjatjara Anangu Pitjantjatjara Anangu, as a symbol in his plea for unity on the lands. Chairman Owen Burton called direct from Parliament House in Adelaide in order to discuss over the radio a new overview committee initiated by the liberals to review the situation on the lands. Brady translated. Frank Young stopped by en route to his community of Watarru. He said that if the status quo on the Lands prevails, everything would fall apart: 'We put in lots of work when we were young. Now we have to do something to keep things going'.

On Thursday, 29 August 2002, the Rolling Thunder Campaign convened in Watarru, one of the more remote and distant communities on the lands. Frank Young became the predominant speaker. Twelve people gathered in the community center. The larger audience stretched across the lands.

${ }^{8}$ Rumor had it that the SA government considered replacing the Pitjantjatjara 
Lands Rights Act. There are currently three plans on the table. Overall, according to details that vary within each of the plans, the state government would replace the AP Executive with a state-appointed body. This move would negate any AP Constitution. In essence, the people, currently wards of the state, would lose all self-determination. They would lose whatever remaining dignity they currently have. On the one hand, it might lead to better governance. On the other hand, decision makers would be at a distance. Or, decision-makers would be made up of corrupt, self-interested Anangu like those opponents who appear to be doing everything within their power to undermine AP. By selling out the people, those individuals destroy whatever possibility remains for sorting out the complex problems that will ultimately destroy Anangu culture.

${ }^{9}$ Petrol sniffing endures as one of the most serious and prevalent forms of substance abuse on the lands. An individual can acquire a small quantity of petrol, place it in a metal can and use it to remain stoned throughout the day. The council has prohibited the sale and possession of alcoholic beverages.

${ }^{10}$ Some communities treat petrol sniffing as an illness. As a first move, they have made sure that petrol sniffers have received enough support to purchase food. Next, they set up activities such as football and work to encourage young fellas to stop sniffing. Finally, they sought clinical help. Community representatives admitted that their actions would not alleviate the problem overnight. They did claim that with everything in place, this substance abuse will gradually disappear in perhaps four years' time.

${ }^{11}$ The South Australian Parliament approved the Pitjantjatjara Lands Rights Act in 1981 .

${ }_{12}$ Accusations leveled against the seat of centralised governance call to mind the American conservatives' repeated diatribe against the federal government Washington D.C., naturally before they assumed control.

\section{References}

Michaels, E. (1994). Bad Aboriginal art: Tradition, media, and technological horizons. Minneapolis: Universityh of Minnesota Press.

O’Regan, T. (1993). Australian television culture. St Leonards, Sydney: Allen \& Unwin.

Associate Professor David I. Tafler is Head of the Communication Department, Muhlenberg College, Allentown, USA. 